\title{
75. COCCOLITH AND SILICOFLAGELLATE STRATIGRAPHY, CENTRAL NORTH ATLANTIC OCEAN, DEEP SEA DRILLING PROJECT LEG 37
}

\author{
David Bukry, United States Geological Survey, La Jolla, California
}

\section{INTRODUCTION}

Leg 37 of the Deep Sea Drilling Project, May to July 1974, which began at Rio de Janeiro, Brazil, and ended at Dublin, Ireland (Figure 1), recovered 154 cores at four drilling sites, Sites $332-335$, near the axis of the Mid-Atlantic Ridge. Light-microscope techniques were used to study 80 samples for coccolith and silicoflagellate stratigraphy. Coccolith zonation (Figure 2) is based on Bukry (1975a), silicoflagellate zonation on Martini (1971) and Bukry and Foster (1973). Two new subspecies of silicoflagellates, Dictyocha perlaevis ornata $\mathrm{n}$. subsp. and Distephanus polyactis crassus n. subsp., are described. A new regional silicoflagellate zone, Dictyocha stapedia stapedia Zone, is designated.

\section{MIOCENE COCCOLITHS IN MID-ATLANTIC RIDGE IGNEOUS CRUST}

Coring of sediment and basalt near the Project FAMOUS site at Deep Sea Drilling Project Site 334, about $104 \mathrm{~km}$ west of the median valley of the MidAtlantic Ridge, shows the sediment-basalt contact at 259 meters subbottom, directly below a late Miocene Discoaster bellus Subzone coccolith ooze. Even older coccoliths from limestone and chalk-breccia horizons within the basement section (which also contains gabbro and serpentinite breccia) can be correlated with middle Miocene coccolith zones. A limestone at 303 meters subbottom contains a moderately overgrown diverse assemblage of the Catinaster calyculus Subzone. The deepest sample examined, from 322 meters, is a gabbro-peridotite-chalk breccia containing thickly overgrown coccoliths that indicate the middle Miocene Catinaster coalitus or Discoaster hamatus zones. The coccolith evidence suggests about a 2-m.y. difference in age between the assemblage at 259 meters subbottom, just above the youngest basalt flow, and that at 322 meters, within a breccia possibly formed at a former wall of the rift valley.

\section{SITE SUMMARIES}

\section{Site 332 \\ (lat $36^{\circ} 52.72^{\prime} \mathrm{N}$, long $33^{\circ} 38.46^{\prime} \mathrm{W}$, depth $1818 \mathrm{~m}$ )}

Site 332 , located $34 \mathrm{~km}$ west of the median valley of the Mid-Atlantic Ridge, was drilled to obtain a long section of cores from the upper part of the igneous rock layers of the ocean crust. Sediment recovery totaled 36.4 meters, igneous rock 151.8 meters. To maximize coring time in the igneous crust, most of the sediment section at Site 332 and other sites of Leg 37 was washed away instead of being cored.
Coccoliths are abundant and well preserved in all of the samples examined; they range from late Pliocene to late Pleistocene in age; the Pliocene-Pleistocene boundary interval was not cored at this site. The oldest coccolith assemblage above basalt, in Sample 332B-1-5, 9$10 \mathrm{~cm}(148 \mathrm{~m})$, contains common Discoaster asymmetricus, few D. tamalis, and lacks Reticulofenestra pseudoumbilica or Sphenolithus abies, and is, therefore, assigned to the Discoaster tamalis Subzone. Coccolith assemblages here and at other Leg 37 sites are distinctive for the high relative abundance of species of Discolithina and Scyphosphaera, reflecting reduced solution of coccoliths at the shallow depth of the ridge flank (Bukry, 1971a; Roth and Berger, 1975). A few specimens of Braarudosphaera bigelowii occur in Core 332-1 (0 to $7 \mathrm{~m})$. Species of Ceratolithus are generally rare or sporadic because of the mid-latitude setting of Site 332 and other Leg 37 sites. Ceratolithus is rare or absent in Pliocene and Pleistocene assemblages from latitudes greater than $35^{\circ} \mathrm{N}$ or $35^{\circ} \mathrm{S}$. Reduced temperature and greater annual change in incident radiation are probably responsible for this general limitation, observed at previously cored DSDP sites, including DSDP Site 116 (lat $57^{\circ} \mathrm{N}$ ), DSDP Site 207 (lat $37^{\circ} \mathrm{S}$ ), and DSDP Site 310 (lat $37^{\circ} \mathrm{N}$ ).

Silicoflagellates are absent or rare in the majority of samples from Site 332 . The most abundant silicoflagellate assemblage, from 332B-1-3, 40-41 cm (145 m), is more than $50 \%$ Distephanus (Figure 3), indicating cool-water conditions. No key stratigraphic-marker species used for other regions occur, but Dictyocha stapedia stapedia is considered to have a late Pliocene to Holocene range, and early populations, as seen here and on Leg 34 in the Pacific (Bukry, in press), have a higher proportion of large specimens with small spires than small specimens with high spires. None of the currently proposed late Pliocene zonal units are completely satisfactory for the Site 332 assemblage. Because D. stapedia stapedia has proved to be a cosmopolitan guide species restricted to sediment of Pliocene to Holocene age in the equatorial and northwestern Pacific, a tentative Dictyocha stapedia stapedia Zone is proposed for Leg 37 as the interval between the first $D$. stapedia stapedia and the first Quaternary Mesocena elliptica. Assemblages are indicated in Figure 3. The presence of $M$. elliptica at mid-latitudes in the Atlantic has yet not been demonstrated, but seems likely in view of the Pacific Ocean range of Quaternary $M$. elliptica from latitude $32^{\circ} \mathrm{S}$ at DSDP Site 206 (Dumitrica, 1973) to latitude $32^{\circ} \mathrm{N}$ at Scripps SCAN 23P, $450-452 \mathrm{~cm}$ on Shatsky Rise (Carolyn Glockhoff, personal communication, 1975), and latitude $37^{\circ} \mathrm{N}$ at DSDP Site 310 on Hess Rise (D. Bukry, unpublished data). 


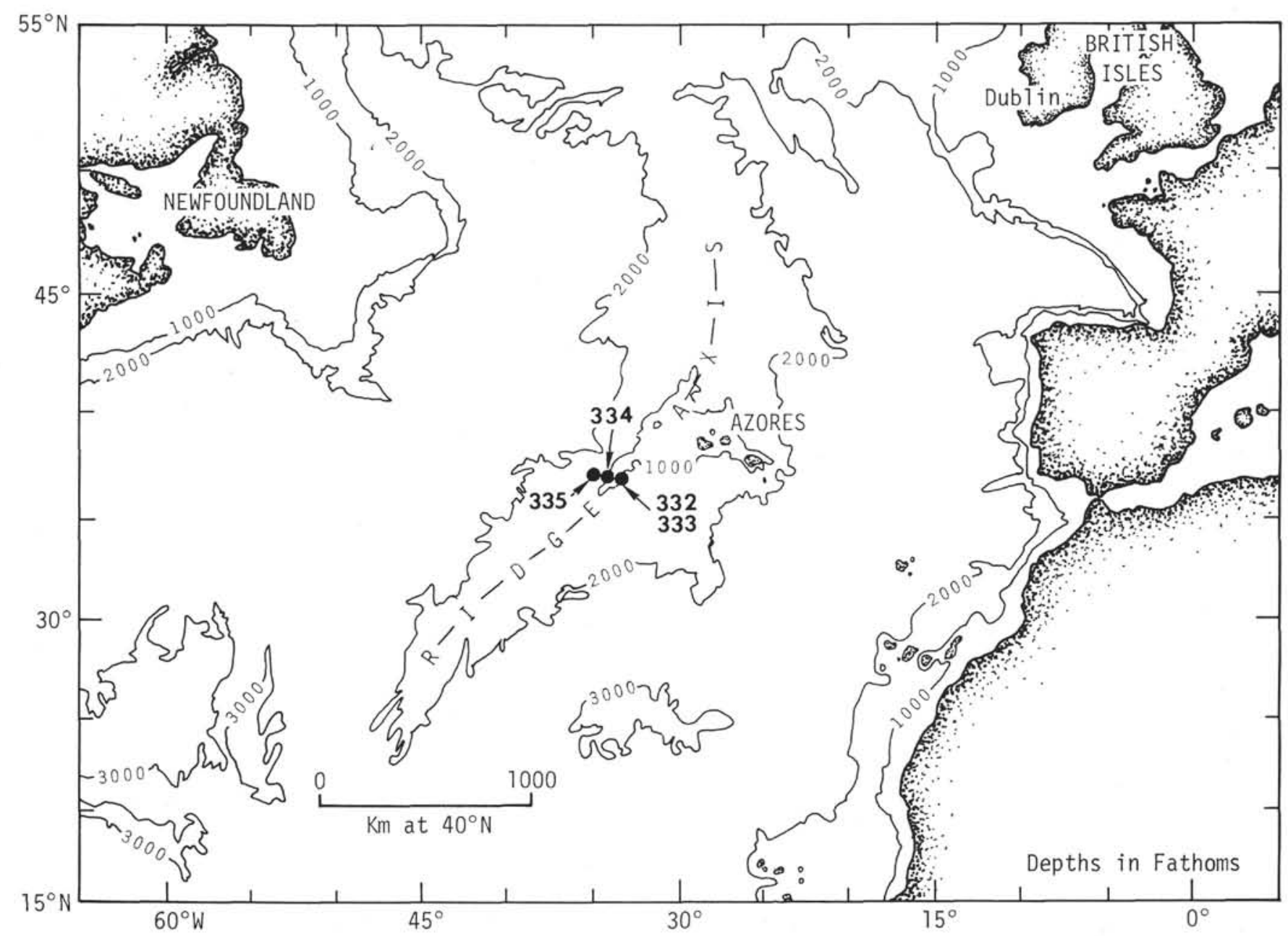

Figure 1. Location of DSDP Leg 37 sites on the Mid-Atlantic Ridge.

Site 333

(lat $36^{\circ} 50.45^{\prime} \mathrm{N}$, long $33^{\circ} 40.05^{\prime} \mathrm{W}$, depth $1666 \mathrm{~m}$ )

Site 333 is just southwest of Site 332 , being $34.3 \mathrm{~km}$ west of the median valley of the Mid-Atlantic Ridge. Sediment was recovered in seven cores above basalt, which was encountered at 219 meters.

Coccoliths are abundant and well preserved. As at Site 332, the genus Scyphosphaera is especially abundant because solution is minimal at shallow locations. The oldest coccolith assemblage examined, Sample 333$7-2,75-76 \mathrm{~cm}(213 \mathrm{~m})$, is late early Pliocene, Discoaster asymmetricus Subzone, based on the occurrence of Reticulofenestra pseudoumbilica and Sphenolithus abies with Discoaster asymmetricus and D. tamalis.

The Pliocene-Pleistocene boundary is probably within the upper part of Core 333-2 (146 to $149 \mathrm{~m}$ ), although its position is unclear because of reworking. The typical sequence of acmes and extinctions among discoasters is belied by the occurrences in Sample 3332-1, 75-76 cm (146 m) (Table 1). Discoaster asymmetricus, $D$. surculus, and $D$. tamalis typically decline in number and become extinct through the upper Pliocene. The reversal in relative abundance shown by all of these species between Samples 333-2-3, 75-76 cm (149 $\mathrm{m})$ and $333-2-1,75-76 \mathrm{~cm}(146 \mathrm{~m})$, together with a marked decline in total discoasters relative to other coccoliths upward through the core, suggest a three- to four-fold increase in reworking-the rare presence of long extinct Amaurolithus delicatus also attests to reworking. It is possible, then, that all of the discoasters in Sample 333-2-1, 75-76 cm (146 m) are reworked and that this sample could be assigned to the basal Pleistocene.

Silicoflagellates are most common in Cores 333-2 and 333-5. Solution thinning of specimens is pervasive for Core 2, less so for Core 5. Of particular interest is the predominance of Dictyocha perlaevis ornata $\mathrm{n}$. sub$\mathrm{sp}$. in Sample 333-2-5, 59-60 cm (152 m). It is apparently a regional stratigraphic marker because it is common at Site 334 , some $147 \mathrm{~km}$ farther west in a sample assigned to the same late Pliocene coccolith subzone. Regionally, it is missing in the few older and younger horizons examined in detail for silicoflagellates (Figure $3)$.

\section{Site 334}

(lat $37^{\circ} 02.13^{\prime} \mathrm{N}$, long $34^{\circ} 24.87^{\prime} \mathrm{W}$, depth $2619 \mathrm{~m}$ )

Site 334 , located $104 \mathrm{~km}$ west of the median valley of the Mid-Atlantic Ridge, was intended to obtain older basalt sequences for comparison with Sites 332 and 333 


\begin{tabular}{|c|c|c|c|c|c|c|c|}
\hline & & & & & Site & & \\
\hline A & & Zone & Subzone & 332 & 333 & 334 & 335 \\
\hline 2 & & Emiliania huxleyi & & $1-1$ & $1-1$ & & \\
\hline Еี & & Gephyrocapsa & Ceratolithus cristatus & & & $1-2$ & \\
\hline E્ & & oceanica & Emiliania ovata & $1 \mathrm{~A}-1$ & & & \\
\hline 苂 & & Crenalithus & Gephyrocapsa caribbeanica & & & & \\
\hline & & doronicoides & Emiliania annula & & $2-1$ & & \\
\hline & & & Cyclococcolithina macintyrei & & $2-3$ & & $1-1 / 14$ \\
\hline & & & Discoaster pentaradiatus & & & & \\
\hline & 苟 & $\begin{array}{r}\text { Discoaster } \\
\text { brouweri }\end{array}$ & Discoaster surculus & $\begin{array}{c}1 \mathrm{~B}-1, \\
2 \mathrm{~A}-2 / 2 \mathrm{~A}-5\end{array}$ & $2-5 / 3-1$ & & $2-2 / 2-3$ \\
\hline క్ల & & & Discoaster tamalis & $\begin{array}{l}3 \mathrm{~A}-3 / 6 \mathrm{~A}-2, \\
1 \mathrm{~B}-2 / 1 \mathrm{~B}-5\end{array}$ & $3-5 / 7-1,1 \mathrm{~A}-1$ & & $2-4 / 3-1$ \\
\hline $\bar{a}$ & & Reticulofenestra & Discoaster asymmetricus & & $7-2$ & & \\
\hline & 를 & pseudoumbilica & Sphenolithus neoabies & & & & \\
\hline & & & Ceratolithus rugosus & & & & $2-5$ \\
\hline & & Amaurolithus & Ceratolithus acutus & & & & \\
\hline & & & Triquetrorhabdulus rugosus & & & $2-1$ & $4-2 / 4-3$ \\
\hline & & Discoaster & Amaurolithus primus & & & $2-3 / 3-2$ & \\
\hline & ฐ & quinqueramus & Discoaster berggrenii & & & $4-1 / 7-1$ & \\
\hline & & Discoaster & Discoaster neorectus & & & $7-5 / 12-4$ & \\
\hline Еँّ & & neohamatus & Discoaster bellus & & & $13-2 / 14-1$ & \\
\hline$\stackrel{\Xi}{0}$ & & Discoaster & Catinaster calyculus & & & $20-2$ & \\
\hline$\Sigma$ & & hamatus & Helicopontosphaera kamptneri & & & 220 & \\
\hline & चี & Catinaster coalitu. & & & & $22-2$ & \\
\hline & 党 & Discoaster & Discoaster kugleri & & & & $5-1$ \\
\hline & & exilis & Coccolithus miopelagicus & & & & \\
\hline & & Sphenolithus hete & norphus & & & & \\
\hline
\end{tabular}

Figure 2. Coccolith zonation of sediment from the Mid-Atlantic Ridge, DSDP Leg 37. Numbers assigned to zonal intervals are core-section numbers. Where several samples are assigned to a zone, the highest and lowest sections are listed with a slash between. Cores from second and third drill holes at the same site are distinguished by $A$ or $B$ designations.

\begin{tabular}{|c|c|c|c|c|c|c|c|c|c|c|c|c|c|c|c|c|c|c|c|}
\hline Age & Zone & $\begin{array}{c}\text { Sample } \\
\text { (Interval in } \mathrm{cm} \text { ) }\end{array}$ & 咅 & : & పัँّ & वे. & $\dot{0}$ & & $\begin{array}{l}2 \\
0\end{array}$ & $\begin{array}{c}\vdots \\
\vdots \\
\vdots\end{array}$ & & & 8 & : & ถั้ & 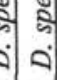 & के & के & \\
\hline \multirow[t]{3}{*}{ Pleistocene } & \multirow{2}{*}{$\begin{array}{r}\text { Dictyocha } \\
\text { aculeata }\end{array}$} & $334-1-1,76-76$ & 1 & 300 & 19 & & & & & & & 8 & & & & & & & 1 \\
\hline & & $333-2-1,75-76$ & 146 & 50 & & 2 & & & & 2 & 12 & 4 & & & & & & & 28 \\
\hline & \multirow{4}{*}{$\begin{array}{c}\text { Dictyocha } \\
\text { stapedia } \\
\text { stapedia }\end{array}$} & $335-2-3,75-76$ & 128 & 300 & & & 2 & 3 & 12 & 39 & 12 & 1 & 1 & $<1$ & & $1<1$ & & 5 & 21 \\
\hline \multirow{3}{*}{$\begin{array}{c}\text { Late } \\
\text { Pliocene }\end{array}$} & & $333-2-5,59-60$ & 152 & 300 & & & & 1 & 52 & 14 & 4 & 1 & & & $<1$ & 2 & & $\leq 1$ & 7 \\
\hline & & $333-5-2,75-76$ & 195 & 300 & & & 3 & & & 27 & 15 & 2 & \begin{tabular}{l|l}
4 & 1 \\
\end{tabular} & 1 & 1 & & & 23 & \begin{tabular}{l|l}
38 & 6 \\
\end{tabular} \\
\hline & & $332 \mathrm{~B}-1-3,40-41$ & 145 & 320 & & & & $<$ & & 10 & 14 & $2 \mid 2$ & & & $<1$ & & $<1$ & & \\
\hline
\end{tabular}

Figure 3. Occurrence of Pliocene and Pleistocene silicoflagellates at DSDP Leg 37 sites recorded as percent of total specimens. Excepting the Dictyocha aculeata Zone at DSDP 334, the assemblages are not readily assigned to previously recognized zones; in this paper, they are assigned to the newly named Dictyocha stapedia stapedia Zone.

and to contribute to studies of magnetic stratigraphy. The site is near the center of magnetic anomaly five (considered 9.0-9.5 m.y.). Sediment recovery was 75.4 meters; 24.2 meters of igneous rock was also obtained. 
TABLE 1

Percentages of Discoaster Species Based on Counts of 100 Specimens

\begin{tabular}{|c|c|c|c|}
\hline \multirow[b]{3}{*}{ Discoaster species } & \multicolumn{2}{|c|}{ Late Pliocene } & I Pleistocene \\
\hline & \multicolumn{3}{|c|}{ Site 333 Sample } \\
\hline & $\begin{array}{c}2-5,54-60 \\
\mathrm{~cm}(152 \mathrm{~m})\end{array}$ & $\begin{array}{c}2-3,75-70 \\
\mathrm{~cm}(149 \mathrm{~m})\end{array}$ & $\begin{array}{c}2-1,75-76 \\
\mathrm{~cm}(146 \mathrm{~m})\end{array}$ \\
\hline D. brouweri & 23 & 78 & 40 \\
\hline D. pentaradiatus & 66 & 11 & 25 \\
\hline D. surculus & 10 & 5 & 21 \\
\hline D. triradiatus & 1 & 1 & - \\
\hline D. asymmetricus & - & 2 & 6 \\
\hline D. tamalis & - & 3 & 8 \\
\hline
\end{tabular}

Note: Discoaster abundance decreases upward through Core 2. Increased percentages of $D$. asymmetricus, $D$. surculus, and $D$. tamalis near the top of the core is believed to indicate reworking.

Two coccolith assemblages from carbonate layers between basalt flows were examined; both are of late middle Miocene age. The Catinaster calyculus Subzone of Sample 334-20-2, 77-89 cm (303 m) contains the following guide species: Catinaster calyculus, Discoaster hamatus, and D. neohamatus. An even older middle Miocene assemblage occurs in an interflow-breccia sample, 334-22-2, 104-108 cm (322m). Coccoliths are abundant but thickly overgrown. Stratigraphically, the presence of common or abundant Cyclococcolithina macintyrei and Reticulofenestra pseudoumbilica, a few Discoaster sp. cf. D. exilis, D. sp. cf. D. variabilis, and rare Coccolithus miopelagicus and the absence of Cyclicargolithus floridanus and five-rayed discoasters indicate the upper middle Miocene.

Most of the sediment of Site 334 is from a thick upper Miocene interval sampled by continuous coring in Cores 2 to 14 (130 to $253 \mathrm{~m})$. Coccoliths and silicoflagellates are abundant and well preserved and indicate rapid and continuous sedimentation.

Coccolith assemblages of the late Miocene Amaurolithus primus Subzone in Cores 2 and 3 suggest relatively warm-water conditions based on the presence of Amaurolithus amplificus (as emended in Gartner and Bukry, 1974), A. delicatus, A primus, Discoaster pentaradiatus, D. quadramus, and $D$. quinqueramus. Discoaster berggrenii and $D$. loeblichii, though not abundant, coexist in the underlying Discoaster berggrenii Subzone (Figure 2). D. loeblichii ranges from Samples 334-12-4, $75-76 \mathrm{~cm}(229 \mathrm{~m})$ to $334-5-4,75-76 \mathrm{~cm}(162 \mathrm{~m})$; it is especially common in Cores 9 and 11 .

Another distinctive feature of the coccolith assemblages is the rarity or absence of Reticulofenestra pseudoumbilica in the interval between Cores 5 and 12 , where Coccolithus pelagicus is especially abundant. $R$. pseudoumbilica is common in the top and bottom of the upper Miocene interval. A similar gap in the range of $R$. pseudoumbilica has been noted in the eastern equatorial Pacific and Gulf of Mexico (Bukry, 1973a). Whereas a broad paleotemperature fluctuation might be expected to cause such a change among the dominant placoliths, the Discoaster evidence and the evidence from associated silicoflagellates, both for DSDP Leg 16 and for Site 334 show no conclusive direct corre- spondence. Although modern Coccolithus pelagicus is a cool-water species, its late Miocene ancestor could have been a warm-water species, judged by its associated silicoflagellate paleotemperature indicators (Table 2).

Silicoflagellates at Site 334 reflect generally warmwater conditions, having genus Dictyocha dominant over Distephanus in all but Core 5 (Figure 4, Table 2). The single post-Miocene silicoflagellate assemblage at Site 334 (Figure 3) also has Dictyocha dominant and is assigned to the Dictyocha aculeata Zone of late Quaternary age. The entire silicoflagellate-bearing Miocene interval is assigned to the Dictyocha aspera Zone, based on the dominance of Dictyocha aspera aspera, D. brevispina, and $D$. pulchella over $D$. fibula s. ampl. As the silicoflagellate-bearing interval of 80 meters represents only about $1 \mathrm{~m} . y$., each sample that was processed represents the silicoflagellate accumulation of a relatively brief period -150 years. Therefore, the trends in $D$. pulchella abundance and the asperoid/fibuloid ratio (Figure 4, Table 2) portray past populations more validly than would figures for areas of low sedimentation rate.

Stratigraphically, the trend of diminishing numbers of Dictyocha pulchella through the Dictyocha aspera Zone and the appearance of Dictyocha sp. (naviculopsoid) and Mesocena elliptica near the top are somewhat similar to trends in the distribution of these taxa in the western Pacific at DSDP Sites 285, 303, and 304.

Some taxa that help distinguish the late Miocene of the northwestern Pacific, such as Dictyocha aspera clinata, are missing at Site 334. But because the largest populations of $D$. aspera clinata coexist with the largest populations of Dictyocha sp. (naviculopsoid) at DSDP Sites 303 and 304, the assemblages at Site 334 probably represent an older portion of the late Miocene prior to the evolution of $D$. aspera clinata.

Rare medusoid variants of several species of Dictyocha (struts meet directly, no apical bar or plate developed) occur throughout the Miocene section at Site 334. Such variants are noted for Dictyocha brevispina, D. fibula, and D. pulchella, and indicate that Dictyocha medusa Haeckel (1887), because of its rarity and potential polyphyletic origin, is better considered as a phenotypic expression within the genus Dictyocha.

\section{Site 335}

\section{(lat $37^{\circ} 17.74^{\prime} \mathrm{N}$, long $35^{\circ} 11.92^{\prime} \mathrm{W}$, depth $3188 \mathrm{~m}$ )}

Site $335,182 \mathrm{~km}$ west of the median valley of the Mid-Atlantic Ridge, was cored to sample igneous crust older than that previously obtained on Leg 37. Recovery totaled 17.8 meters of sediment and 41.5 meters of igneous crust.

Coccoliths are abundant and well preserved in all five sediment cores. The coccoliths above basalt $(450 \mathrm{~m})$ in Sample 335-5-1, 116-117 cm (449 m) are assigned to the middle Miocene Discoaster kugleri Subzone at approximately 13-14 m.y. (Bukry, 1975c). Species present include: Coccolithus eopelagicus, C. miopelagicus, Cyclococcolithina macintyrei, Discoaster challengeri, $D$. exilis, D. sp. cf. D. kugleri, D. variabilis, Helicopontosphaera kamptneri, Reticulofenestra pseudoumbilica, Sphenolithus neoabies, and Triquetrorhabdulus rugosus. 


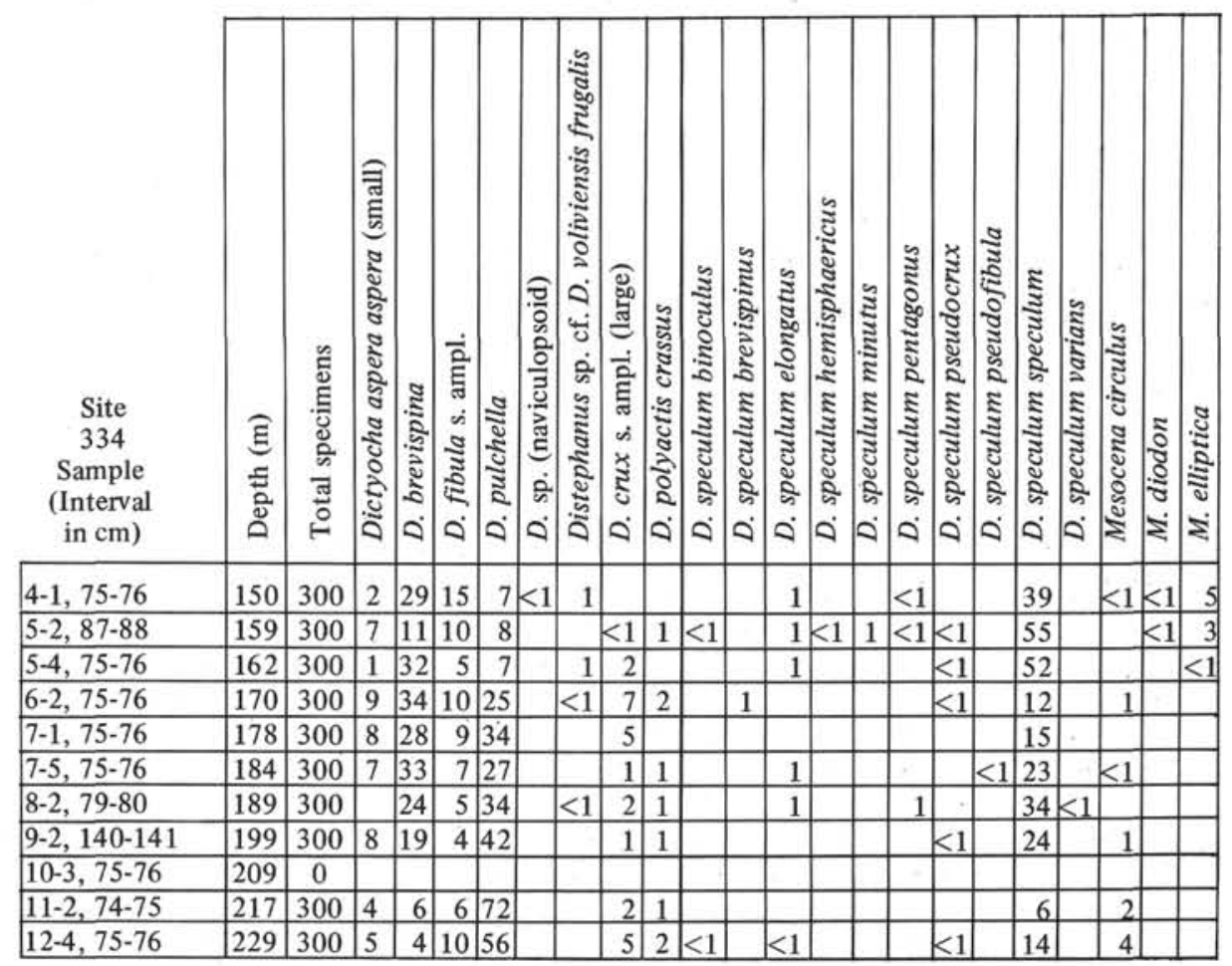

Figure 4. Occurrence of late Miocene silicoflagellates at Site DSDP 334 recorded as percent of total specimens. All samples are assigned to the Dictyocha aspera Zone.

TABLE 2

Summary of Paleotemperature and Stratigraphic Indicator Ratios for Late Miocene Silicoflagellate Assemblages at Site 334

\begin{tabular}{|c|c|c|c|}
\hline \multicolumn{2}{|c|}{ Site 334} & \multirow[b]{2}{*}{ Dictyocha/Distephanus } & \multirow[b]{2}{*}{$\begin{array}{c}\text { Dictyocha Form Groups } \\
\text { Asperoid/Fibuloid }\end{array}$} \\
\hline $\begin{array}{c}\text { Sample } \\
\text { (Interval } \\
\text { in } \mathrm{cm} \text { ) }\end{array}$ & $\begin{array}{l}\text { Depth } \\
(\mathrm{m})\end{array}$ & & \\
\hline $4-1,75-76$ & 150 & $161 / 122=1.3$ & $116 / 44=2.6$ \\
\hline $5-2,87-88$ & 159 & $110 / 179=0.6$ & $79 / 31=2.6$ \\
\hline $5-4,75-76$ & 162 & $133 / 166=0.8$ & $119 / 14=8.5$ \\
\hline $6-2,75-76$ & 170 & $233 / 64=3.6$ & $202 / 31=6.5$ \\
\hline $7-1,75-76$ & 178 & $239 / 61=3.9$ & $211 / 28=7.5$ \\
\hline $7-5,75-76$ & 184 & $223 / 76=2.9$ & $200 / 22=9.1$ \\
\hline $8-2,79-80$ & 189 & $187 / 113=1.7$ & $173 / 14=12.4$ \\
\hline $9-2,140-141$ & 199 & $221 / 77=2.9$ & $210 / 11=19.1$ \\
\hline $10-3,75-76$ & 209 & - & - \\
\hline $11-2,74-75$ & 217 & $267 / 28=9.5$ & $248 / 19=13.1$ \\
\hline $12-4,75-76$ & 229 & $221 / 66=3.4$ & $192 / 29=6.6$ \\
\hline
\end{tabular}

Note: High Dictyocha/Distephanus ratios indicate warm paleotemperatures. A reversal in dominance from asperoid to fibuloid forms of Dictyocha serves to divide the late Miocene into two biostratigraphic zones at low latitude (Martini, 1971).

Among the Pliocene samples examined, the stratigraphy of Samples 335-2-5, 75-76 cm (131 m) and 335-3$1,75-76 \mathrm{~cm}(221 \mathrm{~m})$ is reversed according to coccoliths, possibly as a result of down-hole displacement. Section 2-5 is characterized by abundant Discoaster variabilis and Reticulofenestra pseudoumbilica and rare Amaurolithus delicatus and Ceratolithus rugosus. Sections 2-4 and 3-1 are distinctly younger, being characterized by abundant Crenalithus doronicoides and Cyclococcolithina macintyrei and few to common $C$. rugosus, Discoaster asymmetricus, and D. tamalis.
Silicoflagellates are most abundant in Sample 335-2$3,75-76 \mathrm{~cm}(128 \mathrm{~m})$, where the common occurrence of Dictyocha perlaevis ornata helps to correlate the late Pliocene phytoplankton assemblages of Site 335 with those of Site 333 (Figures 2, 3).

\section{SILICOFLAGELLATE SYSTEMATIC PALEONTOLOGY}

Genus DICTYOCHA Ehrenberg, 1837

Dictyocha aculeata (Lemmermann) Dumitrica

Dictyocha fibula var. aculeata Lemmermann, 1901, Deutsche Bot. Ges., Ber., v. 19, p. 261, pl. 11, fig. 1, 2. 
Dictyocha fibula var. aculeata Lemmermann, Ling, 1972, Am. Paleontol. Bull., v. 62 , p. 161 , pl. 25 , fig. $16,17$.

Dictyocha epiodon Ehrenberg, Bukry and Foster, 1973, DSDP Initial Rept., v. 16, p. 826 , pl. 2, fig. 7, 8 .

Dictyocha aculeata (Lemmermann) Dumitrica, 1973, DSDP Initial Rept., v. 21, p. 849, pl. 4, fig. 9-11.

not Dictyocha epiodon Ehrenberg, Locker, 1974, Eclog. Geol. Helv., v. 67 , p. 634 , pl. 1 , fig. $1,4,5,7,8$.

Remarks: The designation of a lectotype and paralectotype for Dictyocha epiodon Ehrenberg by Locker (1974) from the original Miocene Richmond material supersedes the prior selection of a neotype by Bukry and Foster (1973) based on Ehrenberg's Holocene North Atlantic Ocean figured specimen (International Code of Botanical Nomenclature, Art. 7, Note 3). Dictyocha fibula var. aculeata Lemmermann becomes the earliest name available, and elevation to species rank (Dumitrica, 1973) is appropriate. $D$. epiodon, as now typified, is simply a group of irregular Dictyocha fibula s. ampl.

As a result of the taxonomic change from Dictyocha epiodon to Dictyocha aculeata, the name of the D. epiodon Zone (Bukry and Foster, 1973) is changed to the $D$. aculeata Zone. The D. aculeata Zone (Bukry and Foster, 1973) based on the range of D. aculeata is only approximately equivalent to the $D$. aculeata Zone (Dumitrica, 1973) based on the last occurrence of Mesocena sp. cf. M. elliptica.

\section{Dictyocha perlaevis ornata n. subsp.} (Plate 1, Figures 1-6)

Dictyocha fibula Ehrenberg, Bukry and Foster, 1973 (in part), DSDP Initial Rept., v. 16, p. 826, pl. 2, fig. 9.

?Dictyocha stapedia Haeckel, Dumitrica, 1973, DSDP Initial Rept., v. 21 , p. 862 , pl. 3, fig. 13-15.

Description: Dictyocha perlaevis ornata has a nonornamented apical bar aligned with the major axis of the basal ring. The struts are equant and join the apical bar to the basal ring symmetrically such that the major-axis portals are equant but smaller than the minor-axis portals. The ornamentation of the basal ring is distinctive. In addition to the usual basal-ring pikes, at or near the struts, the basal ring is characterized by eight radially directed pikes that are symmetrically located. A slightly angular-appearing periphery for the basal ring results from this ornamentation.

Remarks: Dictyocha perlaevis ornata is distinguished from nearly all other species of Dictyocha by the symmetric set of eight peripheral pikes or protrusions of the basal ring. The only similar taxon Dictyocha aculeata has only one peripheral pike per quadrant instead of two, and its apical bar is distinctly canted (see Bukry and Foster, 1973, pl. 2, fig. 7-9). D. perlaevis ornata is usually smaller than associated smooth-ringed $D$. perlaevis perlaevis. The full set of eight peripheral pikes may not be developed in all members of a population.

Occurrence: Dictyocha perlaevis ornata is known from the late Pliocene at DSDP Sites 157 and 206 in the Pacific Ocean and DSDP Sites 333 and 335 in the Atlantic Ocean. All of the occurrences are correlated by coccoliths to the Discoaster tamalis Subzone or Discoaster surculus Subzone. The great local abundance at Site 335 and its wide distribution for a brief interval suggest a potential stratigraphic use for $D$. perlaevis ornata when its range is more fully documented.

Size: Basal-ring major axis $30-45 \mu \mathrm{m}$; holotype $30 \mu \mathrm{m}$.

Holotype: USNM 220061 (Plate 1, Figure 1).

Paratypes: USNM 220062 to 220066.

Type locality: Sample $335-2-3,75-76 \mathrm{~cm}(128 \mathrm{~m})$, central North Atlantic Ocean.

\section{Genus DISTEPHANUS Stöhr, 1880}

Distephanus polyactis crassus n. subsp. (Plate 1, Figures 7-14)

Distephanus polyactis (Ehrenberg), Dumitrica, 1973 (in part?), DSDP Initial Rept., v. 21, p. 851, pl. 7, ?fig. 12; pl. 9, ?fig. 2.

Description: Distephanus polyactis crassus is a very large subspecies having proportionally wide tubular elements. The apical and basal rings have matched five- to nine-sided symmetry, although most specimens are somewhat irregular. The sides of the basal ring can be straight or convex. Radial spines are short and equant, and basal pikes are absent. The exceptionally wide tubular structures have a granular-appearing surface texture.
Remarks: Distephanus polyactis crassus is distinguished from Distephanus polyactis polyactis by wider tubular construction and less regular geometric froms of lower symmetry. $D$. polyactis crassus apparently represents a late Miocene degeneration from typical populations of $D$. polyactis polyactis (see Dumitrica, 1973). No specimens of regular, normal-tubed, high-symmetry $D$. polyactis polyactis occur with D. polyactis crassus in the late Miocene section at Site 334 on the Mid-Atlantic Ridge.

Occurrence: Distephanus polyactis crassus is a fairly consistent, low-frequency member of late Miocene Dictyocha aspera Zone assemblages at Site 334 in the North Atlantic. Higher symmetry specimens (seven- and eight-sided) are concentrated near the base of the section. Sample $334-6-2,75-76 \mathrm{~cm}(170 \mathrm{~m})$ contains only five- and six-sided specimens; in 334-5-2, 87-88 cm (159 m), all four specimens encountered are five sided.

Size: Basal ring maximum internal diameter 35-60 $\mu \mathrm{m}$; holotype $48 \mu \mathrm{m}$.

Holotype: USNM 220067 (Plate 1, Figures 11, 12).

Paratypes: USNM 220068 to 220071.

Type locality: Sample 334-12-4, 75-76 cm (229 m), central North Atlantic Ocean.

\section{ILLUSTRATION REFERENCES FOR SPECIES CITED}

\section{Coccoliths}

Amaurolithus amplificus (Bukry and Percival), emended - Gartner and Bukry, 1975

A. delicatus Gartner and Bukry - Gartner and Bukry, 1975 A. primus (Bukry and Percival) - Gartner and Bukry, 1975 Braarudosphaera bigelowii (Gran and Braarud) - Bybell and Gartner, 1972

Catinaster calyculus Martini and Bramlette - Martini and Bramlette, 1963

Ceratolithus rugosus Bukry and Bramlette - Bukry and Bramlette, 1968

Coccolithus eopelagicus (Bramlette and Riedel) - Bramlette and Wilcoxon, 1967

C. miopelagicus Bukry, emended - Wise, 1973

C. pelagicus (Wallich) - Hay and Beaudry, 1973

Crenalithus doronicoides (Black and Barnes) - Roth, 1973

Cyclicargolithus floridanus (Roth and Hay) - Bramlette and Wilcoxon, 1967

Cyclococcolithina macintyrei (Bukry and Bramlette) - Bukry and Bramlette, 1969

Discoaster asymmetricus Gartner - Gartner, 1969

D. bellus Bukry and Percival - Bukry and Percival, 1971

D. berggrenii Bukry - Perch-Nielsen, 1972

D. challengeri Bramlette and Riedel - Bramlette and Riedel, 1954

D. exilis Martini and Bramlette - Martini and Bramle-te, 1963

D. hamatus Martini and Bramlette - Martini and Bramlette, 1963

D. kugleri Martini and Bramlette - Martini and Bramlette, 1963

D. loeblichii Bukry - Bukry 1971a

D. neohamatus Bukry and Bramlette - Bukry, 1975b

D. pentaradiatus Tan - Stradner and Papp, 1961

D. quadramus Bukry - Bukry, 1973b

D. quinqueramus Gartner - Perch-Nielsen, 1972

D. surculus Martini and Bramlette - Martini and Bramlette, 1963

D. tamalis Kamptner - Stradner, 1973

D. triradiatus Tan - Bukry, $197 \mathrm{Ib}$

D. variabilis Martini and Bramlette - Martini and Bramlette, 1963

Helicopontosphaera kamptneri Hay and Mohler - Haq, 1973

Reticulofenestra pseudoumbilica (Gartner) - Gartner, 1967

Sphenolithus abies Deflandre - Deflandre and Fert, 1954

Triquetrorhabdulus rugosus Bramlette and Wilcoxon - Bramlette and Wilcoxon, 1967

\section{Silicoflagellates}

Dictyocha aspera aspera Lemmermann - Bukry, 1975a

D. aspera clinata Bukry - Bukry, 1975 a

D. brevispina (Lemmermann) - Bukry, in press

D. fibula fibula Ehrenberg - Ling, 1972

D. medusa Haeckel - Bukry and Foster, 1973

D. pentagona (Schulz) - Bukry and Foster, 1973

D. perlaevis perlaevis Frenguelli - Bukry, in press 
D. pulchella Bukry - Bukry, 1975a

D. stapedia stapedia Haeckel - Bukry, in press

D. stapedia aspinosa Bukry - Bukry, in press

D. sp. (naviculopsoid) - Bukry, in press

Distephamus boliviensis frugalis Bukry - Bukry, 1975a

D. boliviensis major (Frenguelli) - Bukry and Foster, 1973

D. crux (Ehrenberg) - Ling, 1972

D. speculum binoculus (Ehrenberg) - Uchio, 1974

D. speculum brevispinus Lemmermann - Loeblich et al., 1968

D. speculum elongatus Bukry - Bukry, 1975a

D. speculum hemisphaericus (Ehrenberg) - Bukry, 1975c

D. speculum minutus (Bachmann) - Ichikawa et al., 1967

D. speculum pentagonus Lemmermann - Ling, 1972

D. speculum pseudocrux Schulz - Ling, 1972

D. speculum pseudofibula Schulz - Ling, 1972

D. speculum speculum (Ehrenberg) - Martini, 1971

D. speculum varians (Gran and Braarud) - Bukry, 1975c

Mesocena circulus (Ehrenberg) - Bukry, 1975c

M. diodon Ehrenberg - Bukry, 1975c

M. elliptica (Ehrenberg) - Bukry and Foster, 1973

\section{REFERENCES}

Bramlette, M.N. and Riedel, W.R., 1954. Stratigraphic value of discoasters and some other microfossils related to recent coccolithophores: J. Paleontol., v. 28, p. 385-403.

Bramlette, M.N. and Wilcoxon, J.A., 1967. Middle Tertiary calcareous nannoplankton of the Cipero Section, Trinidad, W.I.: Tulane Stud. Geol., v. 5, p. 93-131.

Bukry, D., 1971a. Cenozoic calcareous nannofossils from the Pacific Ocean: San Diego Soc. Nat. History Trans., v. 16, p. 303-327.

, 1971b. Discoaster evolutionary trends: Micropaleontology, v. 17 , p. 43-52.

1973a. Coccolith stratigraphy, Leg 10, Deep Sea Drilling Project. In, Worzel, J.L., Bryant W., et al., Initial Reports of the Deep Sea Drilling Project, Volume 10: Washington (U.S. Government Printing Office), p. 385406.

1973b. Phytoplankton stratigraphy, Deep Sea Drilling Project Leg 20, western Pacific Ocean. In. Heezan, B.C., MacGregor, I., et al., Initial Reports of the Deep Sea Drilling Project, Volume 20: Washington (U.S. Government Printing Office), p. 307-317.

1975a. Coccolith and silicoflagellate stratigraphy, northwestern Pacific Ocean, Deep Sea Drilling Project Leg 32. In Larson, R.L., Moberly R., et al., Initial Reports of the Deep Sea Drilling Project, Volume 32: Washington (U.S. Government Printing Office), p. 672-702.

1975b. Phytoplankton stratigraphy, southwest Pacific, Deep Sea Drilling Project Leg 30. In Andrews, J.E., Packham, G., et al., Initial Reports from the Deep Sea Drilling Project, Volume 30: Washington (U.S. Government Printing Office), p. 539-548.

1975c. Silicoflagellate and coccolith stratigraphy, Deep Sea Drilling Project Leg 29. In Kennett, J.P., Houtz, R.E., et al., Initial Reports of the Deep Sea Drilling Project, Volume 29: Washington (U.S. Government Printing Office), p. 845-872.

, in press. Silicoflagellate and coccolith stratigraphy, southeastern Pacific Ocean, Deep Sea Drilling Project Leg 34. In Hart, S.R., Yeats, R.S., et al., Initial Reports of the Deep Sea Drilling Project, Volume 34: Washington (U.S. Government Printing Office).

Bukry, D. and Bramlette, M.N., 1968. Stratigraphic significance of two genera of Tertiary calcareous nannofossils: Tulane Stud. Geol., v. 6, p. 149-155.

1969. Some new and stratigraphically useful calcareous nannofossils of the Cenozoic: Tulane Stud. Geol. Paleontol., v. 7, p. 131-142.
Bukry, D. and Foster, J.H., 1973. Silicoflagellate and diatom stratigraphy, Leg 16, Deep Sea Drilling Project. In van Andel, T.H., Heath, G.R., et al., Initial Reports of the Deep Sea Drilling Project, Volume 16: Washington (U.S. Government Printing Office), p. 815-871.

Bukry, D. and Percival, S.F., Jr., 1971. New Tertiary calcareous nannofossils: Tulane Stud. Geol. Paleontol., v. 8 , p. $123-146$.

Bybell, L. and Gartner, S., 1972. Provicialism among midEocene calcareous nannofossils: Micropaleontology, v. 18, p. $319-336$.

Deflandre, G. and Fert, C., 1954. Observations sur les coccolithophoridés actuels et fossiles en microscopie ordinaire et électronique: Ann. Paléontologie, v. 40, p. 115-176.

Dumitrica, P., 1973. Paleocene, late Oligocene and postOligocene silicoflagellates in southwestern Pacific sediments cored on DSDP Leg 21. In Burns, R.E., Andrews, J.E., et al., Initial Reports of the Deep Sea Drilling Project, Volume 21: Washington (U.S. Government Printing Office), p. 837-883.

Gartner, S., Jr., 1967. Calcareous nannofossils from Neogene of Trinidad, Jamaica, and Gulf of Mexico: Kansas Univ. Paleontol. Contrib., Paper 29, p. 1-7.

1969. Correlation of Neogene planktonic foraminifer and calcareous nannofossil zones: Gulf Coast Assoc. Geol. Soc. Trans., v. 19, p. 585-599.

Gartner, S. and Bukry, D., 1974. Ceratolithus acutus Gartner and Bukry n. sp. and Ceratolithus amplificus Bukry and Percival-nomenclatural clarification: Tulane Stud. Geol. Paleontol., v. 11, p. 115-118.

1975. Morphology and phylogeny of the coccolithophycean family Ceratolithaceae: U.S. Geol. Surv. J. Res., v. 3, p. 451-465.

Haeckel, E.H.P.A., 1887. Cannorrhaphida: Challenger Rept., v. 18 , p. $1546-1569$.

Haq, B.U., 1973. Evolutionary trends in the Cenozoic coccolithophore genus Helicopontosphaera: Micropaleontology, v. 19 , p. 32-52.

Hay, W.W. and Beaudry, F.M., 1973. Calcareous nannofossils-Leg 15, Deep Sea Drilling Project. In Edgar, N.T., Saunders, J.B., et al, Initial Reports of the Deep Sea Drilling Project, Volume 15: Washington (U.S. Government Printing Office), p. 625-683.

Ichikawa, W., Shimizu, I., and Bachmann, A., 1967. Fossil silicoflagellates and their associated uncertain forms in Iida Diatomite, Noto Peninsula, Central Japan: Kanazawa Univ. Sci. Rept., v. 12, p. 143-172.

Ling, H.Y., 1972. Upper Cretaceous and Cenozoic silicoflagellates and ebridians: Am. Paleontol. Bull., v. 62, p. 135-229.

Locker, S., 1974. Revision der Silicoflagellaten aus der Mikrogeologischen Sammlung von C.G. Ehrenberg: Ecolg. Geol. Helv., v. 67, p. 631-646.

Loeblich, A.R., 3d, Loeblich, L.A., Tappan, H., and Loeblich, A.R., Jr., 1968. Annotated index of fossil and recent silicoflagellates and ebridians with descriptions and illustrations of validly proposed taxa: Geol. Soc. Am. Mem. 106, p. 1-319.

Martini, E., 1971. Neogene silicoflagellates from the equatorial Pacific. In Winterer, E.L., Riedel, W.R., et al., Initial Reports of the Deep Sea Drilling Project, Volume 7: Washington (U.S. Government Printing Office), p. 16951708.

Martini, E. and Bramlette, M.N., 1963. Calcareous nannoplankton from the experimental Mohole drilling: J. Paleontol., v. 37, p. 845-856.

Perch-Nielsen, K., 1972. Remarks on Late Cretaceous to Pleistocene coccoliths from the North Atlantic. In 
Berggren, W.A., Laughton, A.S., et al., Initial Reports of the Deep Sea Drilling Project, Volume 12: Washington (U.S. Government Printing Office), p. 1003-1069.

Roth, P.H., 1973. Calcareous nannofossils-Leg 17, Deep Sea Drilling Project. In Winterer, E.L., Ewing, J.I., et al., Initial Reports of the Deep Sea Drilling Project, Volume 17: Washington (U.S. Government Printing Office), p. 695-795.

Roth, P.H. and Berger, W.H., 1975. Distribution and dissolution of coccoliths in the south and central Pacific: Cushman Found. Foram. Res. Spec. Pub. 13, p. 87-113.

Stradner, H., 1973. Catalogue of calcareous nannoplankton from sediments of Neogene age in the eastern North Atlantic and the Mediterranean Sea. In Ryan, W.B.F., Hsü, K.J., et al., Initial Reports of the Deep Sea Drilling Project, Volume 13: Washington (U.S. Government Printing Office), p. 1137-1199.
Stradner, H. and Papp, A., 1961. Tertiäre Discoasterideriden aus Osterreich und deren stratigraphischen Bedeutung mit Hinweisen auf Mexiko, Rumänien und Italien: Osterreichische Geol. Bundesanst. Jahrb., spec. v. 7, p. 1159.

Uchio, T., 1974. Tertiary nannoplankton stratigraphy of Sado Island, Niigata Prefecture, and a proposal of the Braarudosphaera bigelowi-Coccolithus pelagicus Zone for the Pliocene of Japanese oil fields of Japan Sea side: Japan Geol. Surv. Rept., no. 250-1, p. 235-254.

Wise, S.W., Jr., 1973. Calcareous nannofossils from cores recovered during Leg 18, Deep Sea Drilling Project: Biostratigraphy and observations of diagenesis. In Kulm, L.D., von Hulne, R., et al., Initial Reports of the Deep Sea Drilling Project, Volume 18: Washington (U.S. Government Printing Office), p. 569-615. 


\section{PLATE 1}

New Silicoflagellate Subspecies from DSDP Leg 37

Figures 1-7, 9-14: scale bar equals $10 \mu \mathrm{m}$.

Figure 8: scale bar equals $20 \mu \mathrm{m}$.

Figures 1-6 Dictyocha perlaevis ornata n. subsp.

1. Holotype, USNM 220061, Sample 335-2-3, $75-76 \mathrm{~cm}(128 \mathrm{~m})$.

2. USNM 220062, Sample 333-2-5, 59-60 cm (152 m).

3. USNM 220063, Sample 335-2-3, 75-76 cm $(128 \mathrm{~m})$.

4. USNM 220064, Sample 333-2-5, 59-60 cm (152 m).

5. USNM 220065, Sample 333-2-5, 59-60 cm (152 m).

6. USNM 220066, Sample 333-2-5, 59-60 cm (152 m).

Figures 7-14 Distephanus polyactis crassus n. subsp.

7. USNM 220068, Sample 334-11-2, 74-75 cm $(217 \mathrm{~m})$, fragment, low focus.

8. USNM 220069, Sample 334-12-4, 75-76 cm (229 m).

9, 10. USNM 220070, Sample 334-5-2, 87-88 cm $(159 \mathrm{~m})$.

9. High.

10. Low.

11, 12. Holotype, USNM 220067, Sample 334-124, $75-76 \mathrm{~cm}(229 \mathrm{~m})$.

11. High.

12. Low.

13, 14. USNM 220071, Sample 334-12-4, 75-76 cm $(229 \mathrm{~m})$.

13. High.

14. Low. 
PLATE 1
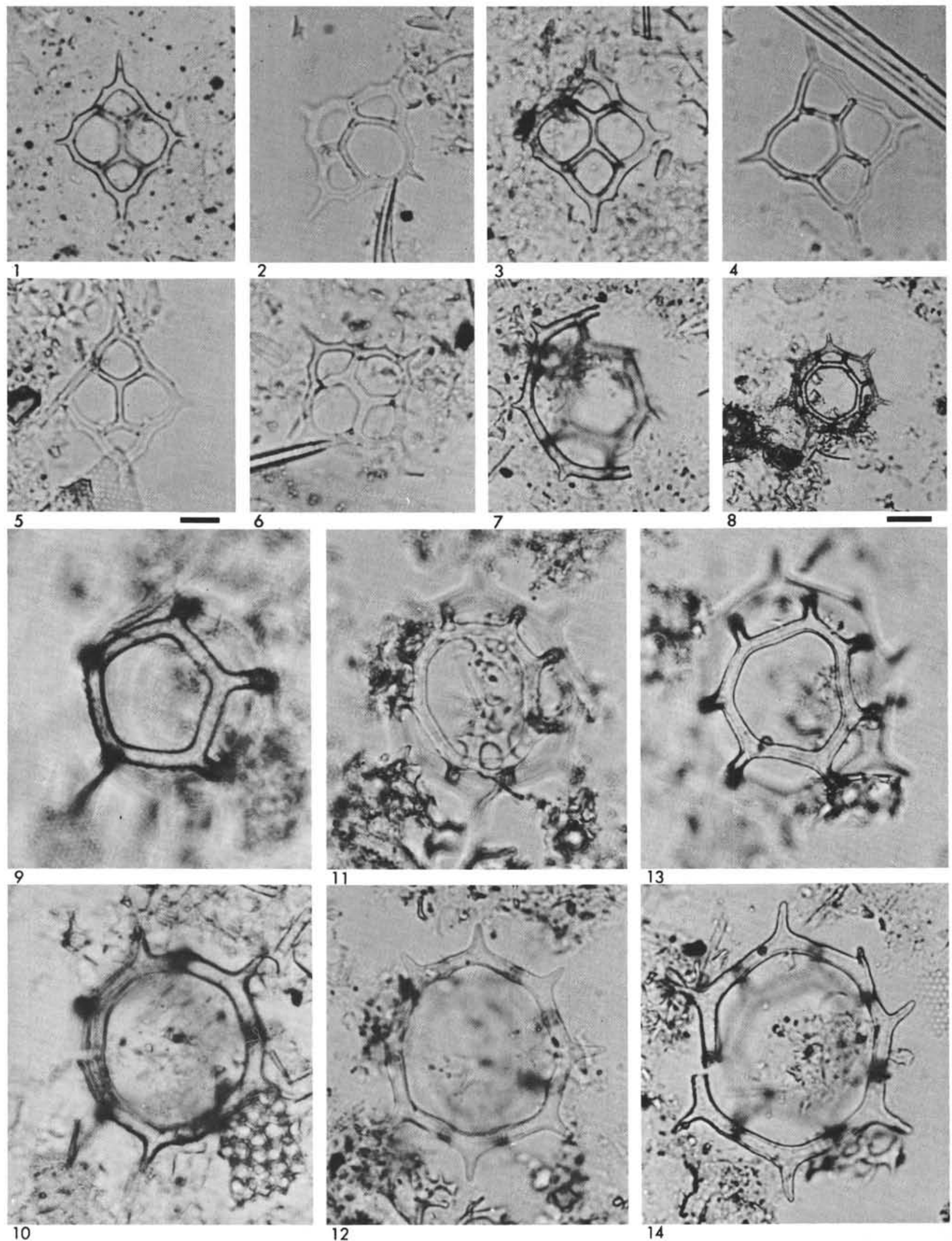